\title{
Order Care Setting Type Code
}

National Cancer Institute

\section{Source}

National Cancer Institute. Order Care Setting Type Code. NCI Thesaurus. Code C153139.

A coded value specifying the level of healthcare (care setting) the patient was in when the order was given. 